\title{
AC 2007-27: THE ENERGY SYSTEMS LABORATORY AT KETTERING UNIVERSITY
}

\author{
Ahmad Pourmovahed, Kettering University \\ Ahmad Pourmovahed is a Professor of Mechanical Engineering at Kettering University. He \\ received his Ph.D. in Mechanical Engineering (1985) and an M.S. in Mechanical Engineering \\ (1979) both from the University of Wisconsin-Madison. After graduation, he worked at General \\ Motors Research Laboratories and Lawrence Technological University. In 1990, he joined \\ Kettering University where he teaches courses in thermal sciences, mechanics, and engineering \\ design and serves as the Director of Energy Systems Laboratory.
}




\title{
The Energy Systems Laboratory at Kettering University
}

\begin{abstract}
Energy Systems Laboratory is a required senior level course for mechanical engineering students at Kettering University (formerly GMI). Approximately 250 students take this course every year. Thermodynamics and Fluid Mechanics serve as pre-requisites for this laboratory course while Heat Transfer is a co-requisite. This class meets six hours a week (two hours of common lecture plus four hours of laboratory experimentation). It deals with detailed application of the first and the second laws of thermodynamics; continuity, momentum, and energy equations; and principles of conduction and convection to a variety of energy systems. A design project is incorporated into this laboratory course. Currently, experiments performed in this laboratory include a Jet Engine, Road Load Simulation, PEM Fuel Cell Performance, Centrifugal Pump, Fan Laws, Compressible Flow, Pipe Flow and Flow Meters, Lift and Drag, Heat Exchanger, and Cylinder Convection. Among other things, the students learn how jet engines work; how aircraft wings produce lift; how a fuel cell works; how supersonic velocities are produced; how to use a dynamometer to predict the gas mileage of a car; how to match pumps and fans to piping systems and ducts and how to cool hot objects effectively. They also learn to apply the fundamental principles of thermodynamics, fluid mechanics and heat transfer in an integrated manner to a variety of energy systems. This paper describes this modern laboratory in detail, presents the course pedagogy as well as a summary of the laboratory experiments including photographs of the equipment and sample results obtained in each experiment.
\end{abstract}

\section{Introduction}

Kettering University (formerly GMI Engineering \& Management Institute) is a fully cooperative institute that offers degree programs in engineering, sciences and management. All undergraduate students alternate between 11-week periods of study on campus and related work experience at one of over 700 corporations. About 55 percent of Kettering University students are enrolled in mechanical engineering.

Every mechanical engineering student at Kettering University takes a senior-level course entitled Energy Systems Laboratory. Thermodynamics and Fluid Mechanics serve as pre-requisites for this laboratory course while Heat Transfer is a co-requisite. This laboratory course provides students with opportunities to apply fundamental concepts learned in core energy systems courses as well as introduces students to modern measurement techniques and modern engineering tools. The course is intended to provide students with an integrated, hands-on experience since courses in the area of energy systems are often taught in isolation.

Among other things, the students learn:

- how jet engines work

- how aircraft wings produce lift

- how a fuel cell works 
- how supersonic velocities are produced

- how to use a dynamometer to predict the gas mileage of a car

- how to match pumps and fans to piping systems and ducts

- how to cool hot objects effectively

The Energy Systems Laboratory also provides research opportunities. The 30-HP re-circulating wind tunnel can be used for research in aero-acoustics and the Digital Particle Image Velocimetry (DPIV) equipment is capable of generating a two-dimensional map of a flow field. A complete Air Delivery System donated by Eaton Corporation and will soon become a part of this laboratory. This system can supply air to a variety of fuel cell systems.

\section{Course Learning Objectives}

Upon completion of this course, the student will be able to:

1. apply the fundamental principles of thermodynamics, fluid mechanics, and heat transfer [ABET's A,E,K].

2. apply modern measurement techniques and experimental methods to energy systems [ABET's A,B,E].

3. apply computational techniques to energy systems [ABET's A,E,K].

4. apply team working skills [ABET's D].

5. communicate effectively [ABET's G].

6. design and conduct experiments [ABET's B,E,K].

7. analyze and interpret data [ABET's B].

8. implement experimental results in a design process[ABET's B,C].

\section{Topics Covered}

$\begin{array}{cl}\text { Week } & \text { Topic } \\ 1 & \text { Safety Guidelines, Error Analysis, Pipe Flow, Flow Meters } \\ 2 & \text { Design Project Initiation, Road Load Simulation } \\ 3 & \text { PEM Fuel Cell Performance } \\ 4 & \text { Centrifugal Pump } \\ 5 & \text { Fan Laws, Introduction to DPIV } \\ 6 & \text { Compressible Flow } \\ 7 & \text { Jet Engine } \\ 8 & \text { Design Projects } \\ 9 & \text { Lift, Drag \& Aerodynamics } \\ 10 & \text { Cylinder Convection } \\ 11 & \text { Final examination and team design projects } \\ & \\ \text { Lecture: } & \text { One session per week of } 120 \text { minutes } \\ \text { Lab: } & \text { Two sessions per week of } 120 \text { minutes each }\end{array}$




\section{MECH-422 Energy Systems Laboratory Representative Lecture/Lab Schedule}

\begin{tabular}{|c|c|}
\hline Winter 2007 & Common Lecture on Wed \\
\hline \multicolumn{2}{|l|}{ Week 1} \\
\hline First Session & Safety Guidelines, Error Analysis \\
\hline Wednesday & Pipe Flow, Flow Meters \\
\hline Second Session & Pipe Flow and Flow Meters, Design Project Initiation \\
\hline \multicolumn{2}{|l|}{ Week 2} \\
\hline First Session & NO LAB (Martin Luther King Holiday) \\
\hline Wednesday & $\underline{\text { Road Load Simulation }}$ \\
\hline Second Session & Road Load Simulation (Engine Lab: Room 1-220 AB) \\
\hline \multicolumn{2}{|l|}{ Week 3} \\
\hline First Session & [QUIZ \#1 Pipe Flow/Flow Meters] \\
\hline Wednesday & PEM Fuel Cell Performance+ Guest Speaker \\
\hline Second Session & PEM Fuel Cell Performance \\
\hline \multicolumn{2}{|l|}{ Week 4} \\
\hline First Session & [QUIZ \#2 Road Load Simulation] \\
\hline$\underline{\text { Wednesday }}$ & Centrifugal Pump and Fan Laws \\
\hline Second Session & Centrifugal Pump \\
\hline \multicolumn{2}{|l|}{ Week 5} \\
\hline First Session & [QUIZ \#3 PEM Fuel Cell Performance] \\
\hline Wednesday & Common Midterm Exam \\
\hline Second Session & Introduction to DPIV (Room 2-224 AB) \\
\hline \multicolumn{2}{|l|}{ Week 6} \\
\hline First Session & Design Project \\
\hline Wednesday & Compressible Flow \\
\hline Second Session & Compressible Flow \\
\hline \multicolumn{2}{|l|}{ Week 7} \\
\hline First Session & [QUIZ \#4 Centrifugal Pump/Fan Laws] \\
\hline Wednesday & Jet Engine \\
\hline Second Session & Jet Engine (First Floor Test Cell, 1123 MC) \\
\hline \multicolumn{2}{|l|}{ Week 8 } \\
\hline First Session & Jet Engine \\
\hline Wednesday & No Lecture \\
\hline Second Session & NO LAB \\
\hline \multicolumn{2}{|l|}{ Week 9} \\
\hline First Session & Design Project \\
\hline Wednesday & $\underline{\text { Lift, Drag \& Aerodynamics }}$ \\
\hline Second Session & Lift, Drag \& Aerodynamics \\
\hline \multicolumn{2}{|l|}{$\begin{array}{r}\text { Week 10 } \\
\end{array}$} \\
\hline First Session & Lift, Drag \& Aerodynamics \\
\hline Wednesday & Cylinder Convection \\
\hline Second Session & Cylinder Convection \\
\hline \multicolumn{2}{|l|}{ Week 11} \\
\hline First Session & Final Design Project Presentations \\
\hline & Common Final Exam \\
\hline
\end{tabular}




\section{Topics Covered in Each Experiment}

Jet Engines

Types of jet engines, thrust force, component efficiencies, energy balance, emissions

Road Load Simulation

Tractive effort, fuel economy, engine efficiency, energy balance

PEM Fuel Cell

Stack voltage, current and efficiency, polarization curves, cell reversal

Centrifugal Pump

Pump performance maps, pump efficiency, operating point

Fan Laws

Fan performance maps, fan static and total efficiencies, fan laws, operating point

Compressible Flow

Subsonic and supersonic flows, normal shock waves, choking

Pipe Flow

Pipe friction and head losses, velocity profiles, laminar and turbulent flow

Flow Meters

Flow measurement using a venturi, nozzle, orifice or laminar flow meter

Lift and Drag

Pressure distribution above and under wings, lift and drag, wing stall

Heat Exchanger

Heat transfer from a hot to a cold fluid stream, LMTD method, NTU method

Cylinder Convection

Temperature variation with angle, wake behind a cylinder, heat transfer coefficient

Refrigeration and Psychrometry

Vapor-compression refrigeration system, coefficient of performance, properties of humid air

Figure 1 shows the cover page of the textbook used in this laboratory course. 


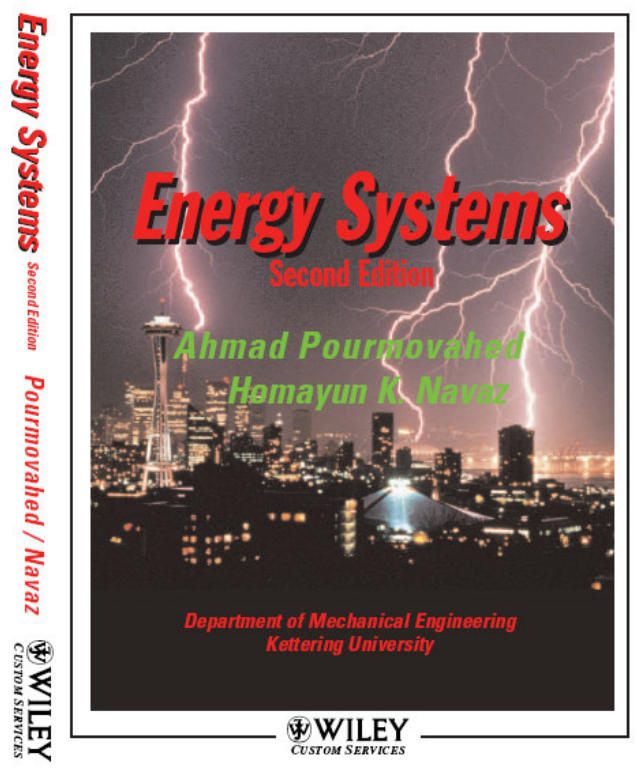

Figure 1: Cover page of the book used for Energy Systems Laboratory

\section{Table of Contents for the textbook used ${ }^{1}$}

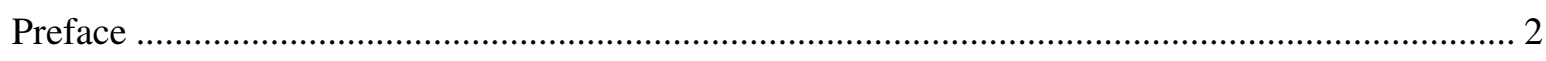

Energy Systems Laboratory Safety Guidelines.......................................................................... 3

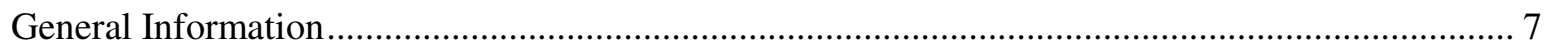

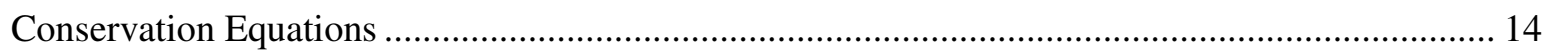

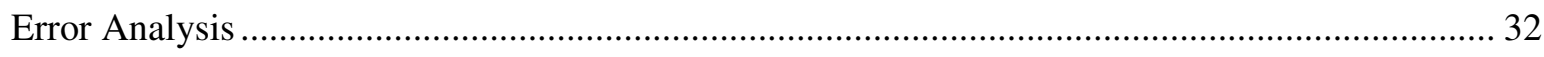

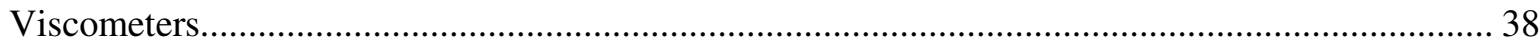

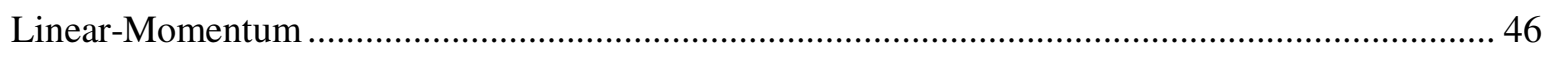

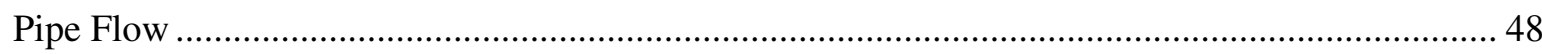

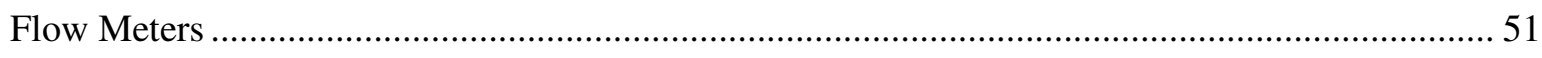

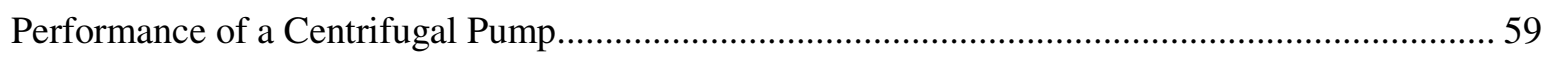

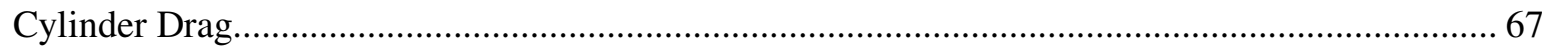

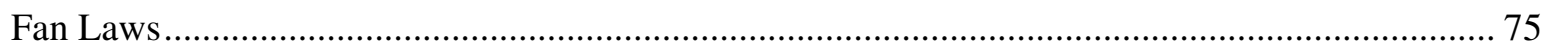

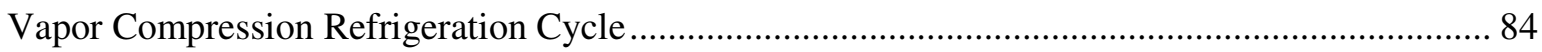

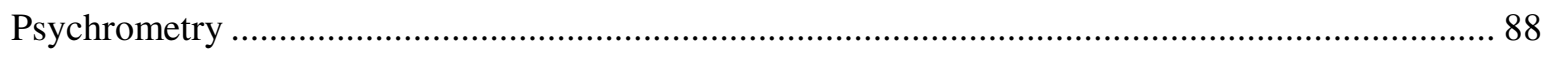

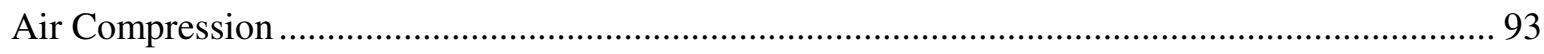

Compressible Flow in a Converging-Diverging Nozzle ........................................................... 96

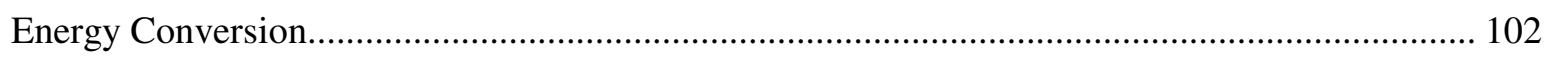

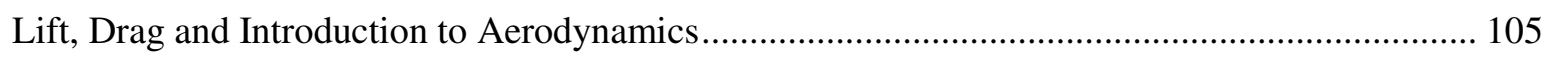

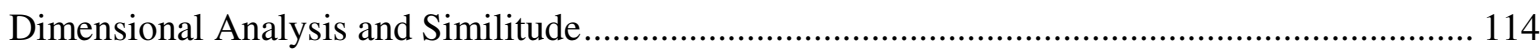
(1) 


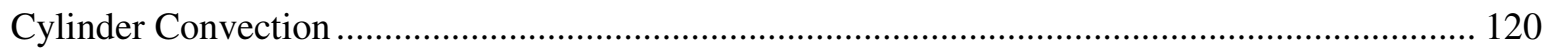

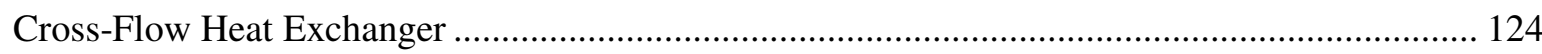

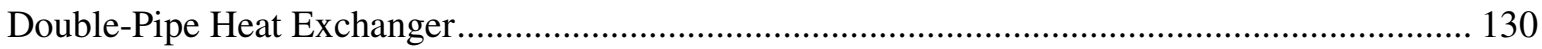

Steady State Road Load Simulation and Engine Energy Balance ............................................. 136

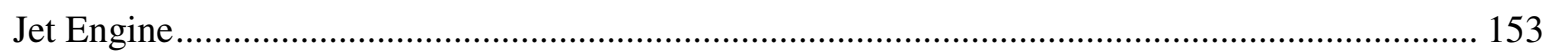

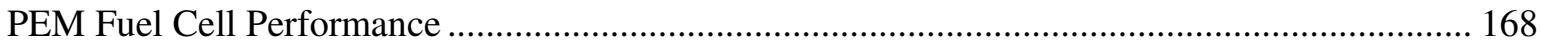

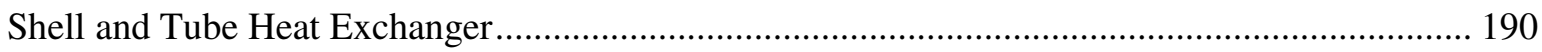

Digital Particle Image Velocimetry (DPIV) ......................................................................... 199

General Standard Operating Procedure for Tempest ND:YAG and Other Equipment ................. 212

Appendix A: Brief Review of Thermodynamics ..................................................................... 218

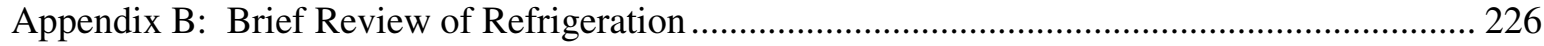

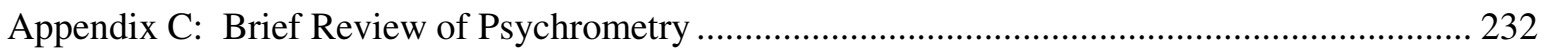

Appendix D: Brief Review of Compressible Flow ….............................................................. 242

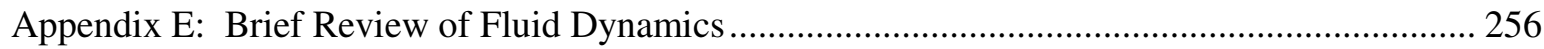

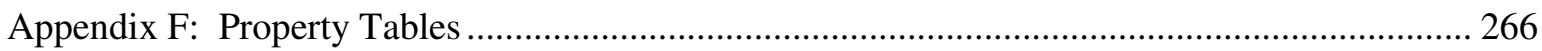

Educational objectives, photographs of the equipment as well as representative data for the experiments currently performed in this laboratory course are shown in Figures 2-21.

\section{Pipe Flow and Flow Meters}

\section{$\underline{\text { Educational Objectives }}$}

1. To apply the Energy Equation to a piping system that includes a fan.

2. To compare experimentally determined friction factors with published values.

3. To demonstrate the theory, use, and calibration of the following types of flow meters: laminar flow meter, venturi, nozzle and flat-plate orifice. 


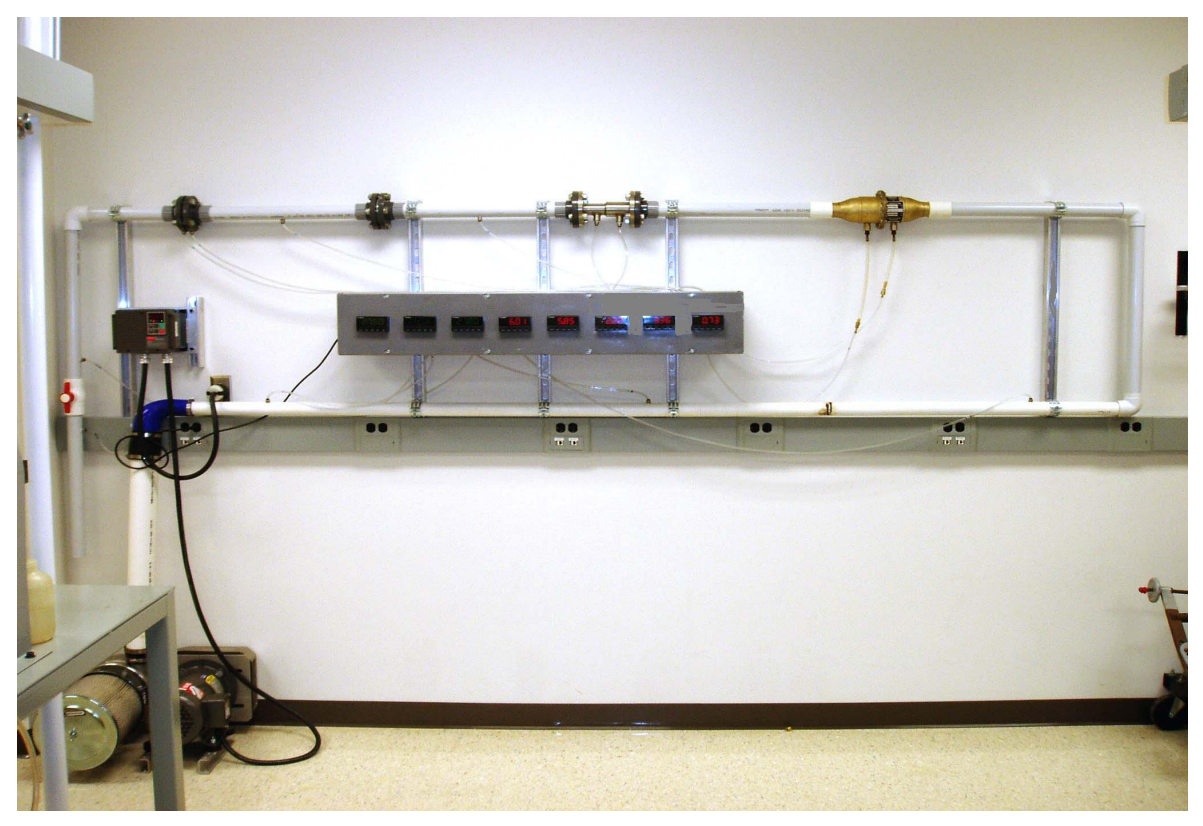

Figure 2: The combined Pipe Flow and Flow Meters setup

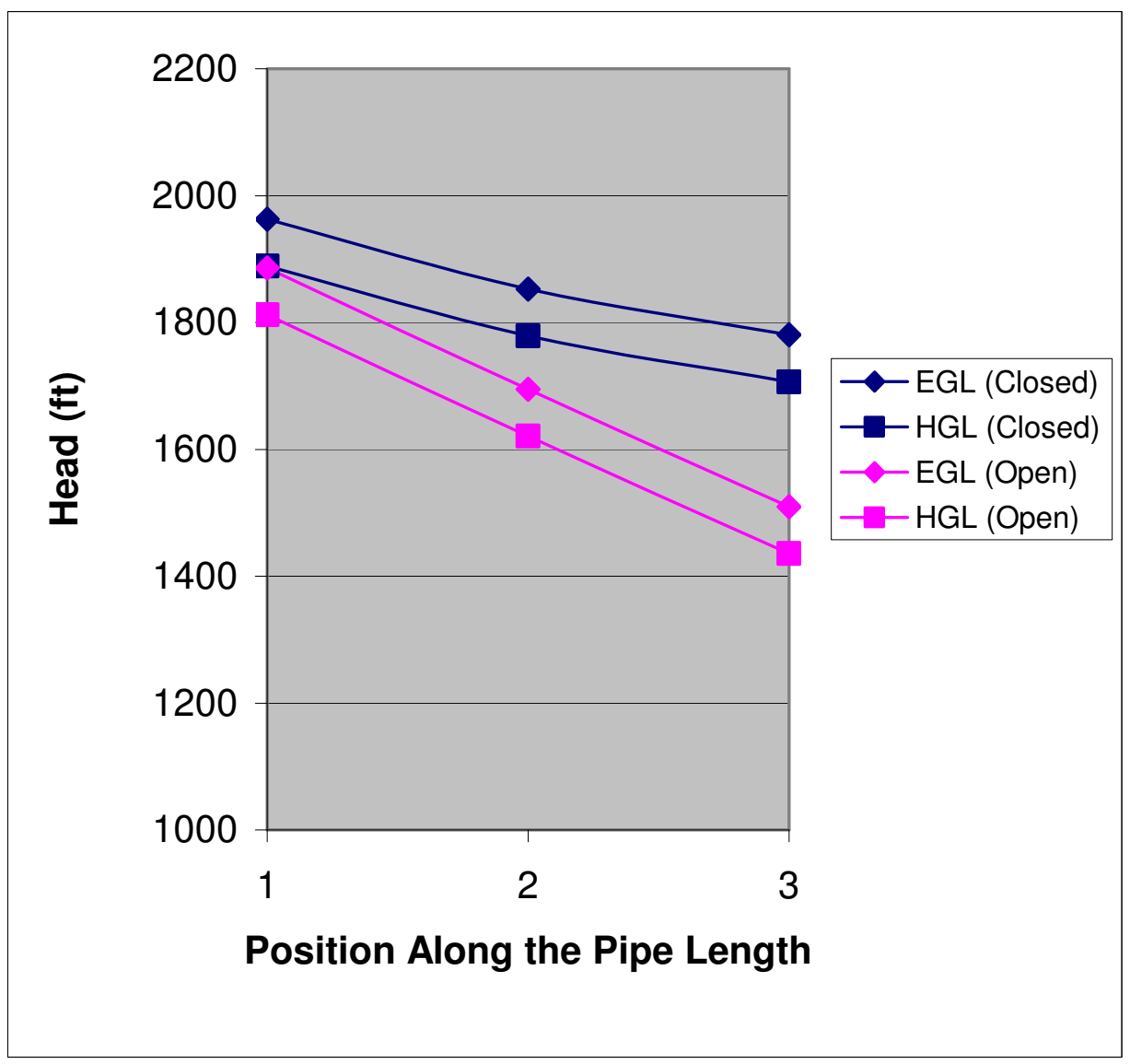

Figure 3: Energy and Hydraulic Grade Lines for the lower pipe

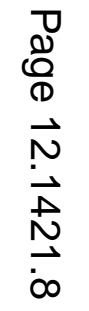




\section{Steady-State Road Load Simulation and Engine Energy Balance}

\section{$\underline{\text { Educational Objectives }}$}

1. To predict, by means of a dynamometer test, the performance of a gasoline engine when installed in an automobile and operated at various speeds in third and fourth gears.

2. To determine the effect of road speed and gear ratio on fuel economy and exhaust emissions.

3. To determine the actual thermal efficiency of the engine.

4. To perform an energy balance on the engine.

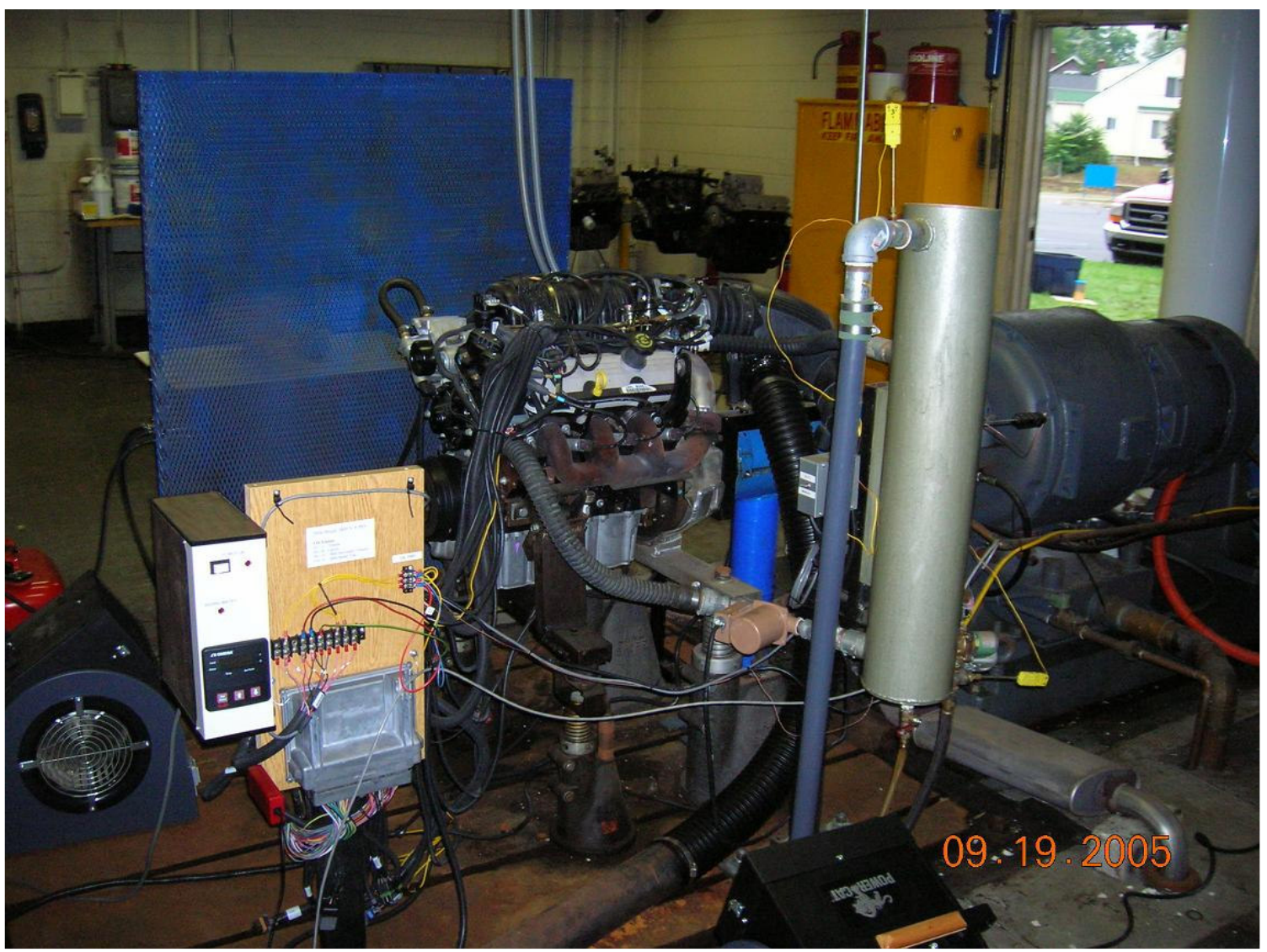

Figure 4: The six-cylinder gasoline engine and the dynamometer 


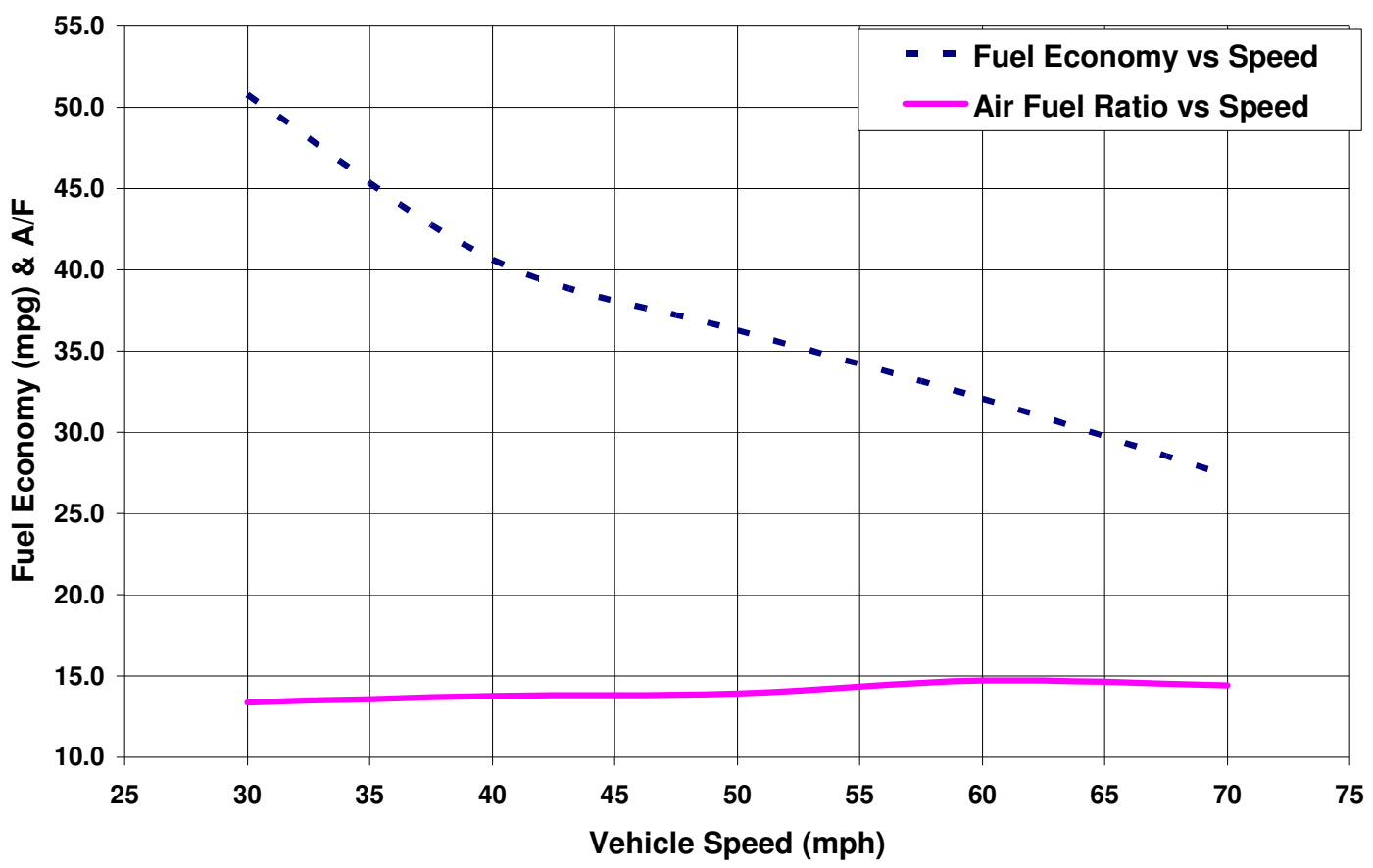

Figure 5: Fuel economy and air fuel ratio $\left(4^{\text {th }}\right.$ gear $)$

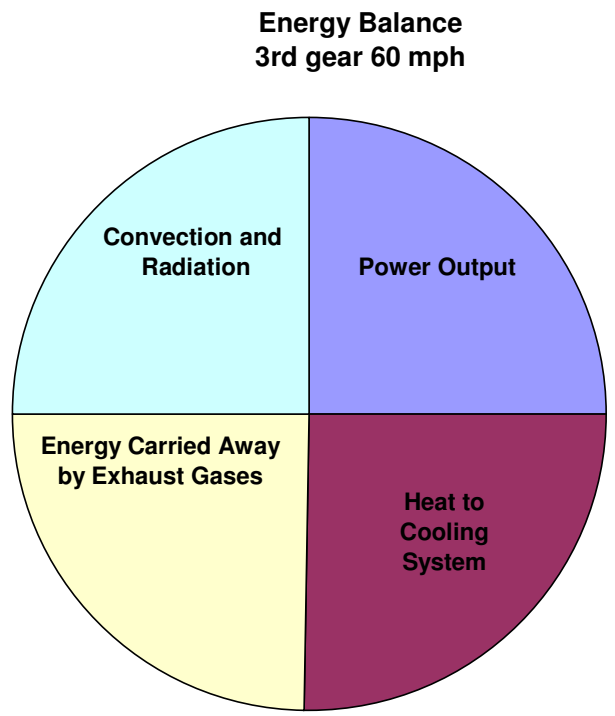

Figure 6: Engine energy balance 


\section{PEM Fuel Cell Performance}

\section{$\underline{\text { Educational Objectives }}$}

1. To familiarize the students with the principles and operation of a PEM fuel cell.

2. To compare the power output efficiency of the fuel cell with that of an IC engine.

3. To determine the effect of current density on stack voltage.

4. To determine the effect of stack temperature on the stack power output.

5. To determine the effect of hydrogen flow rate on the stack power output.

6. To determine the "second-law effectiveness" of the fuel cell.

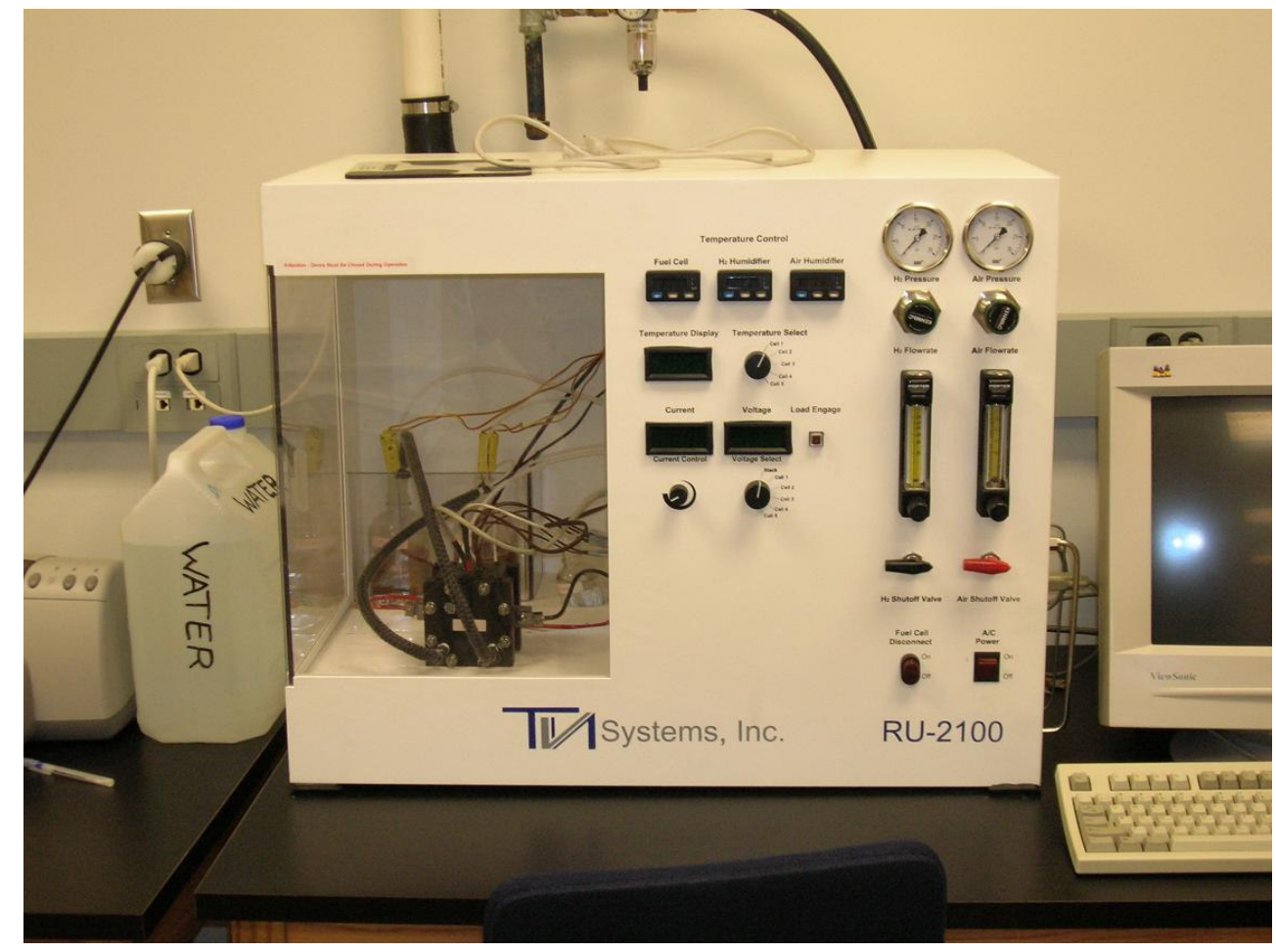

Figure 7: The three-cell PEM fuel cell system 


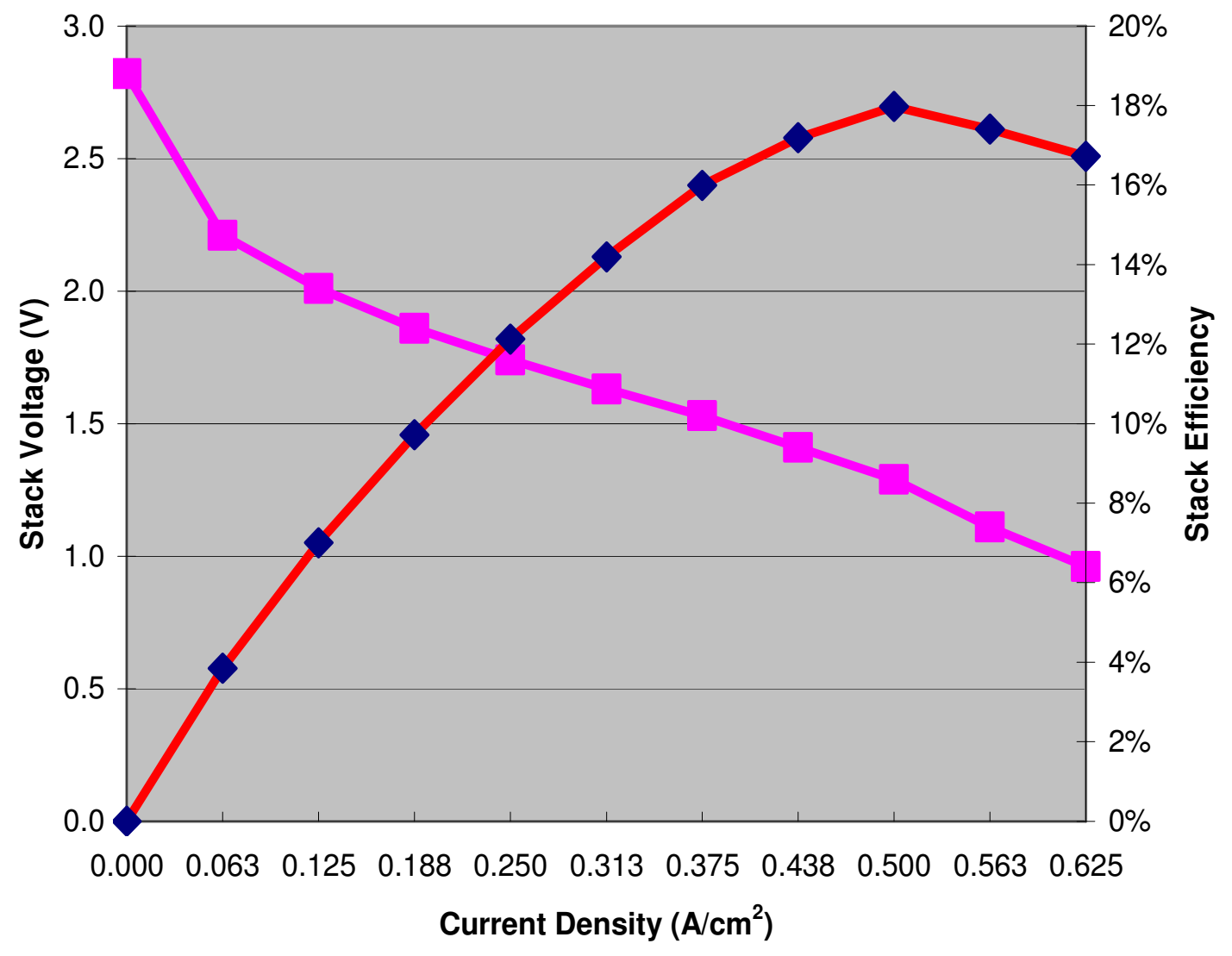

Stack Voltage $\leadsto$ Stack Efficiency

Figure 8: Stack voltage and efficiency versus current density

\section{Performance of a Centrifugal Pump}

\section{Educational Objectives}

1. To familiarize the students with the operation of a centrifugal pump.

2. To provide a thorough understanding of centrifugal pump testing and analysis on the dimensional and dimensionless bases.

3. To familiarize the students with automatic data acquisition. 


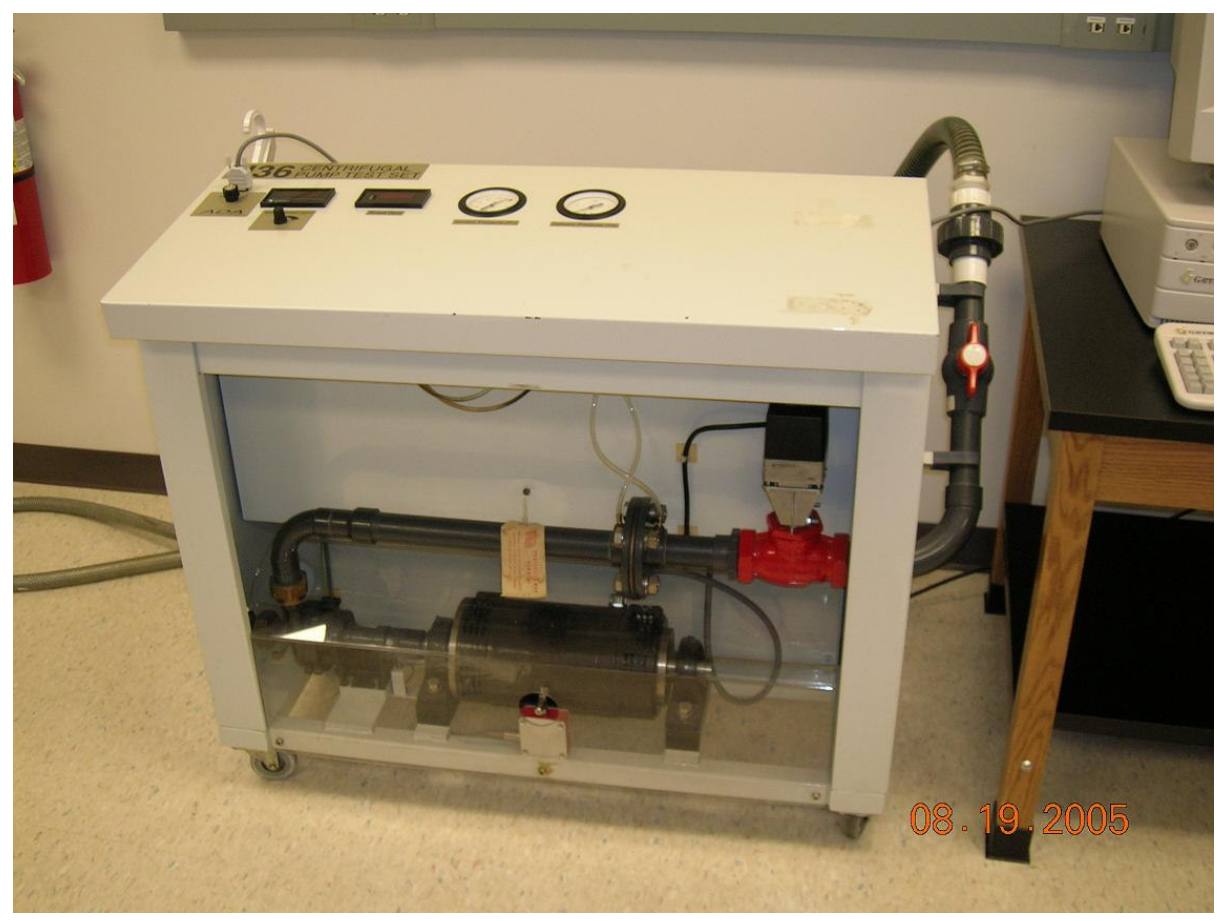

Figure 9: The Centrifugal Pump used to demonstrate pump performance mapping

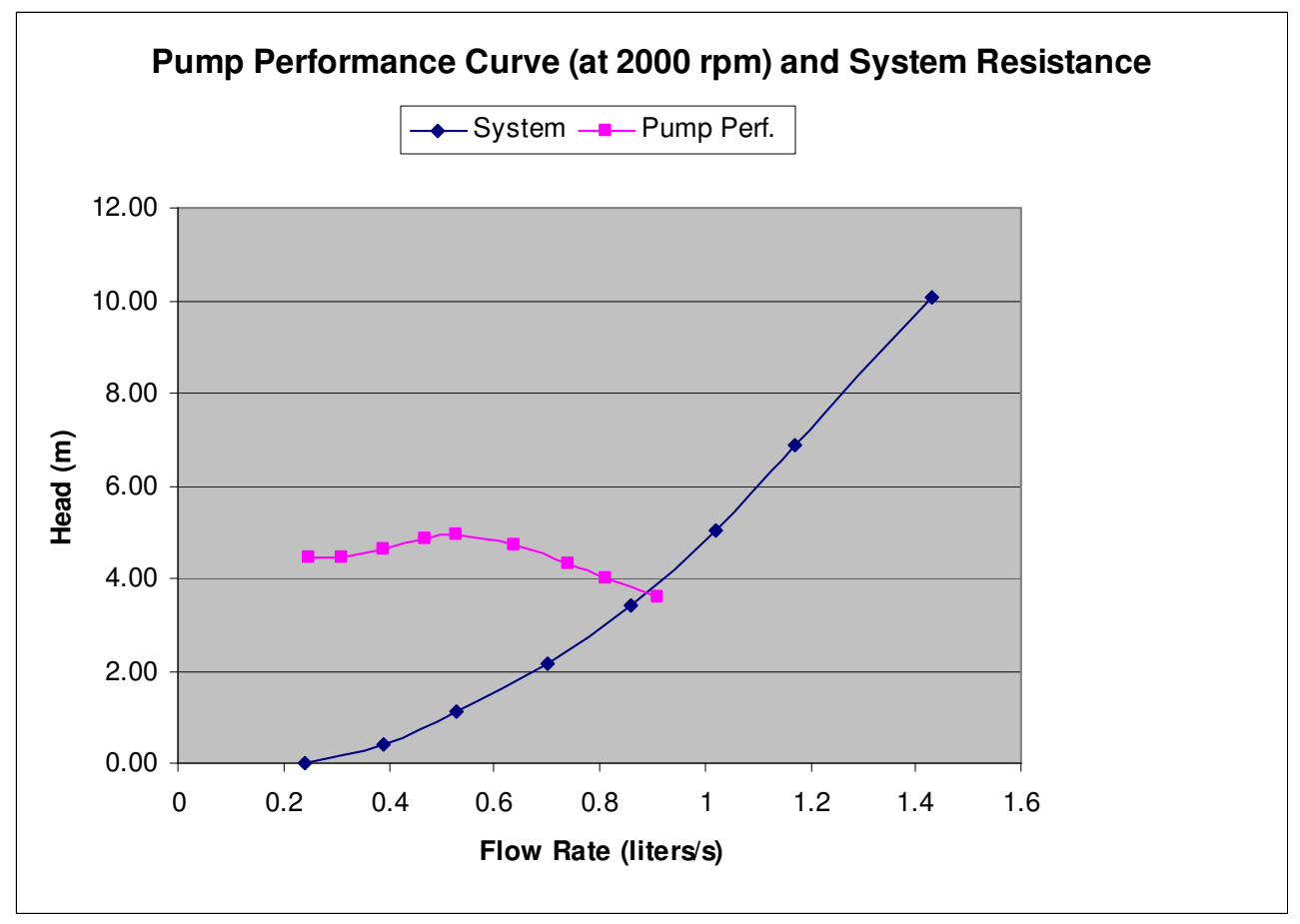

Figure 10: Pump head and system resistance versus flow rate 


\section{Fan Laws}

\section{$\underline{\text { Educational Objectives }}$}

1. To investigate the validity of the fan laws relating speed, volumetric flow rate, static pressure and power.

2. To determine the variation of volumetric flow rate, static pressure, power and efficiency at constant speed.

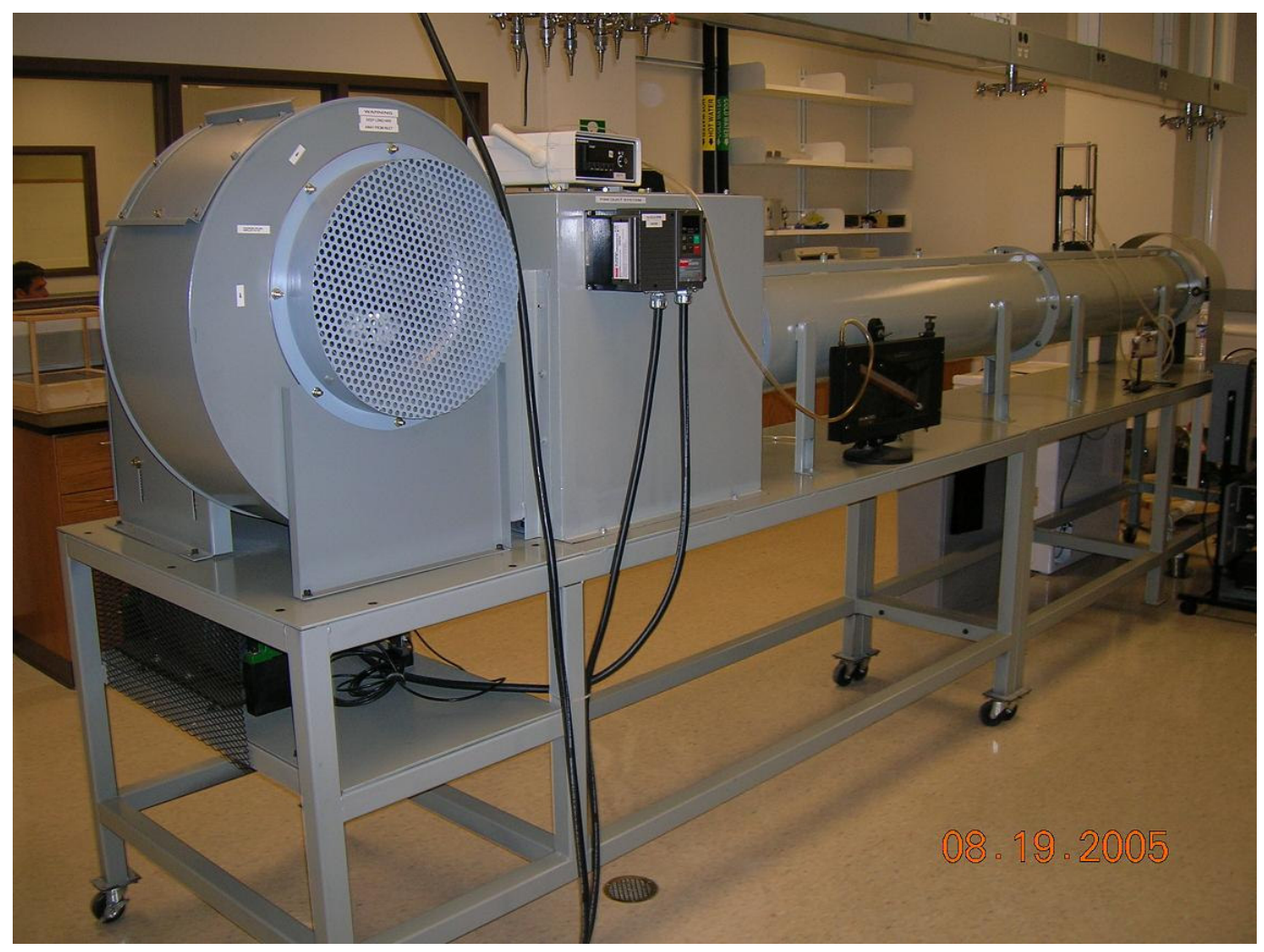

Figure 11: The Centrifugal Fan used to demonstrate "Fan Laws" and fan performance mapping 


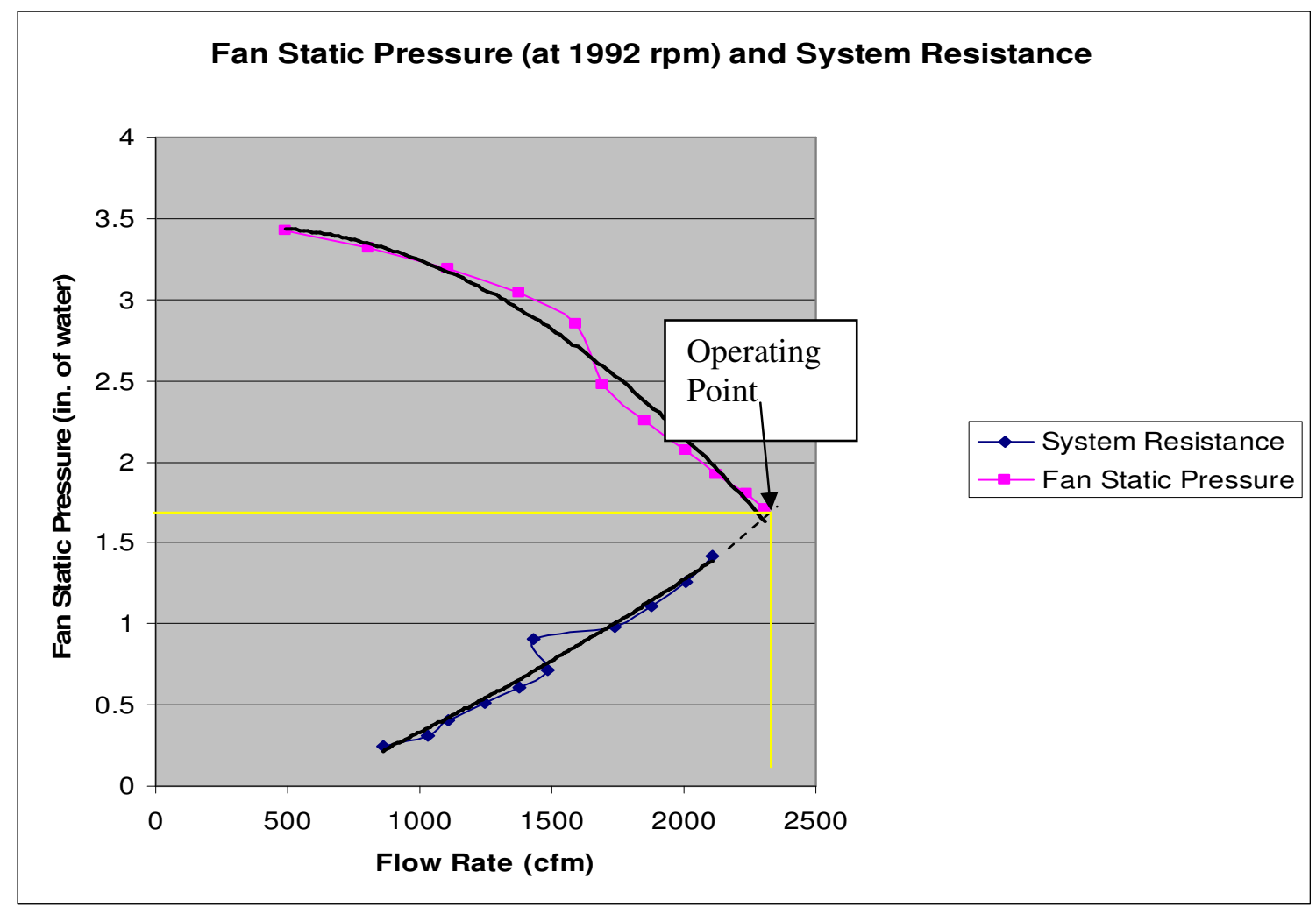

Figure 12: Fan static pressure and system resistance versus flow rate

\section{Compressible Flow in a Converging-Diverging Nozzle}

\section{$\underline{\text { Educational Objectives }}$}

1. To determine the effect of inlet and exit pressures on the static pressure distribution in a converging-diverging nozzle.

2. To determine the effect of exit pressure on the location of a normal shockwave and the pressure rise across the same.

3. To determine the effect of the inlet/exit pressures on the mass flow rate through the nozzle under choked and unchoked conditions.

4. To determine the effect of boundary layer formation inside the nozzle on the mass flow rate. 


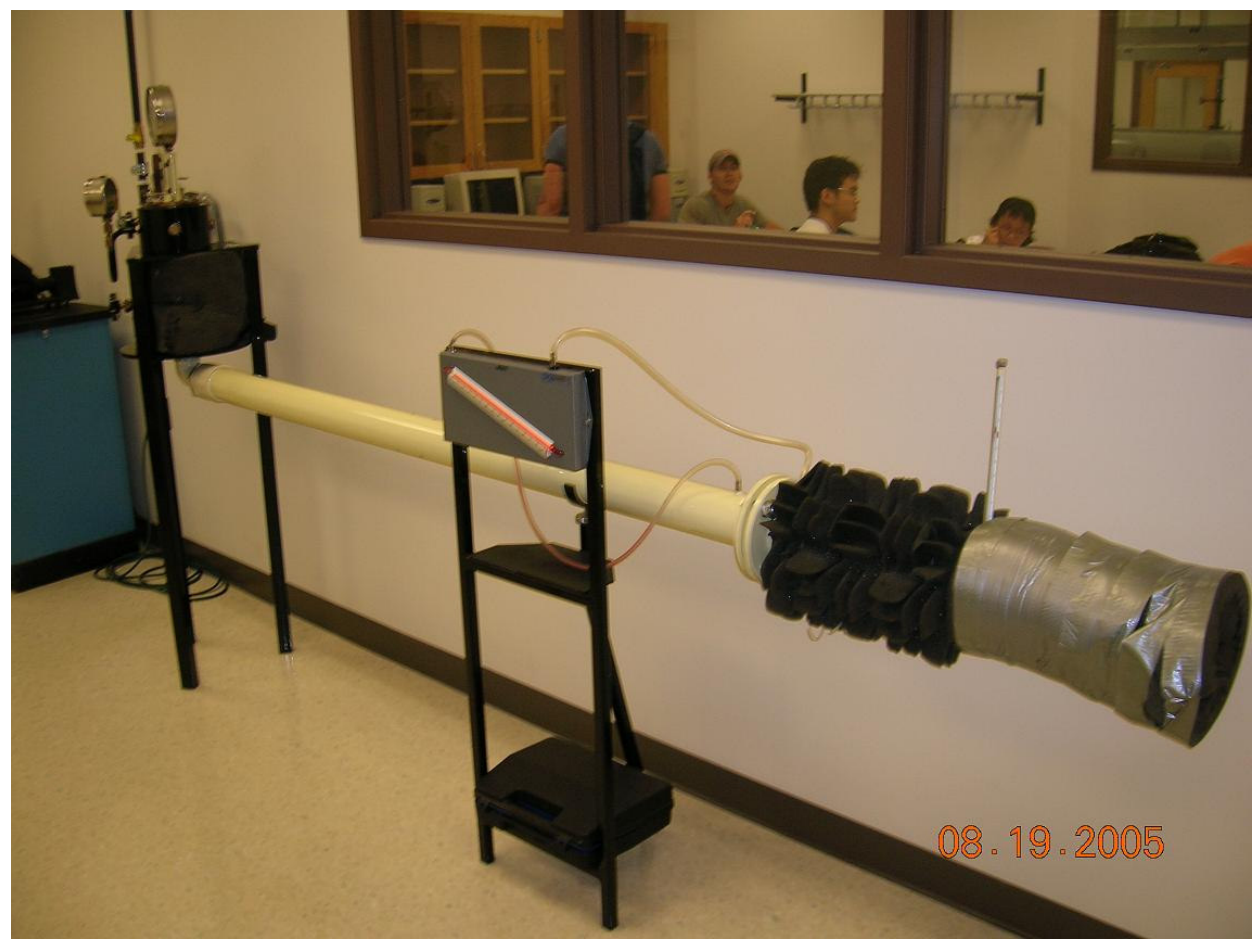

Figure 13: The Compressible Flow apparatus

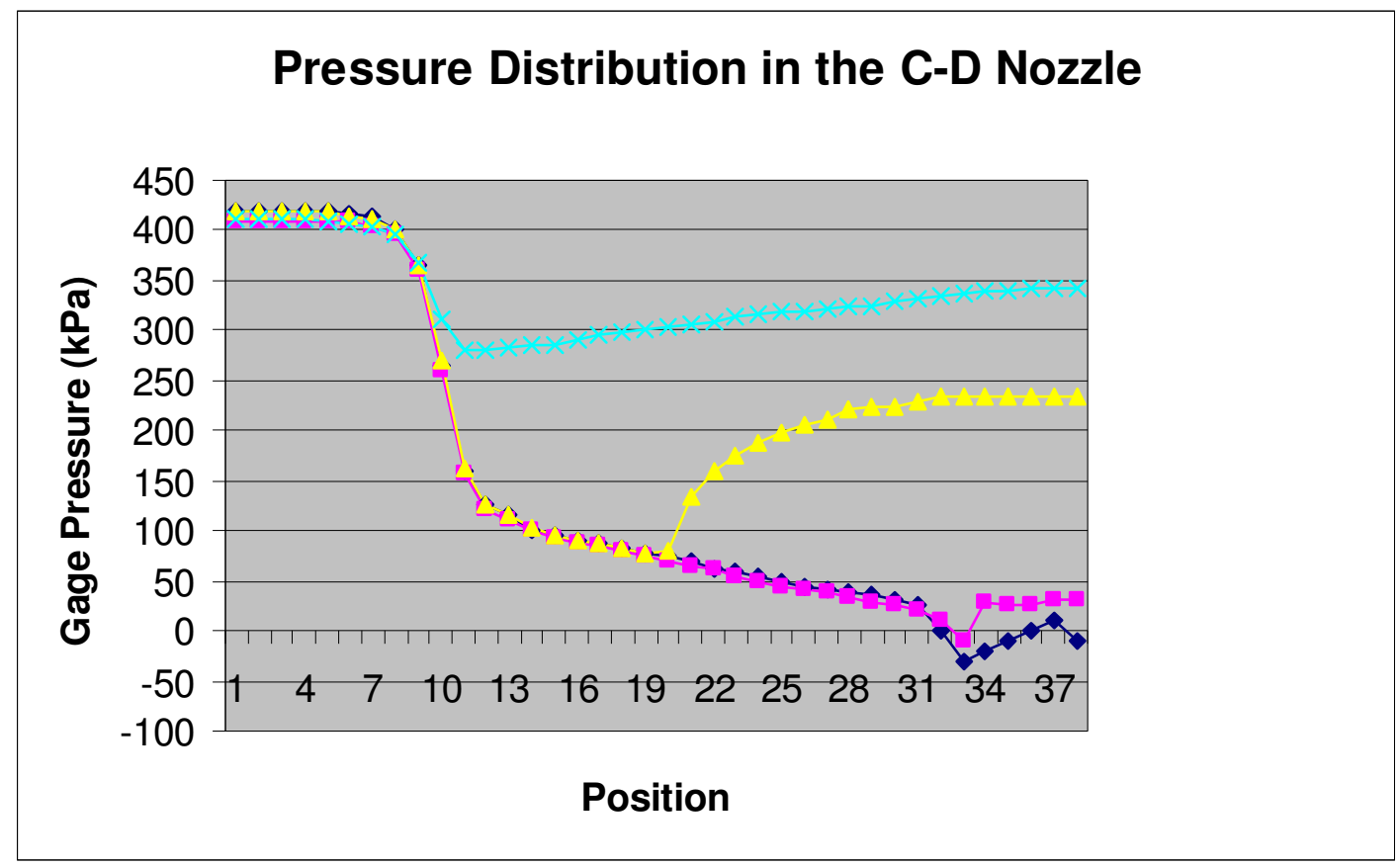

Figure 14: Pressure distribution along the axis of the C-D nozzle 


\section{The Jet Engine}

\section{Educational Objectives}

1. To familiarize the students with the operation of a turbojet engine, the theory behind the thermodynamic processes involved, and the linear momentum equation.

2. To determine theoretical values of engine thrust and the actual efficiencies of the compressor, the combustion chamber and the turbine.

3. To determine the effect of engine speed on the thrust force, thrust-specific fuel consumption, and air-fuel ratio.

4. To perform an energy balance on the jet engine.

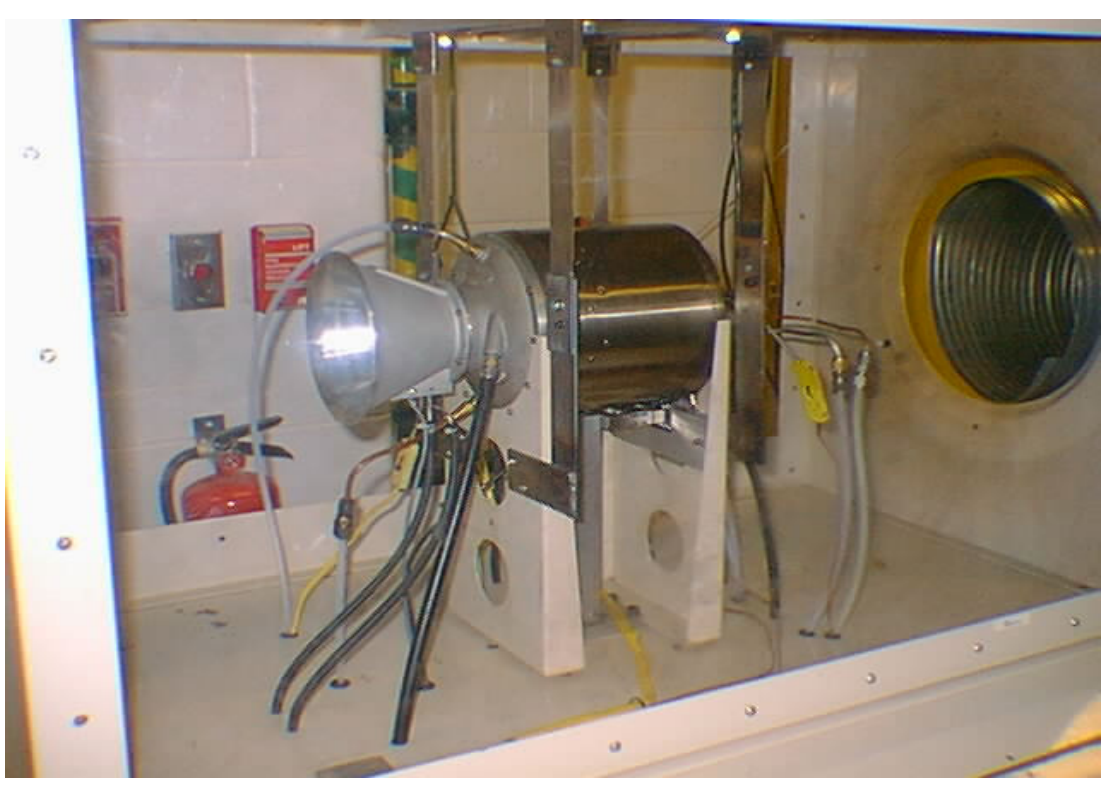

Figure 15: The SR-30 Turbojet Engine

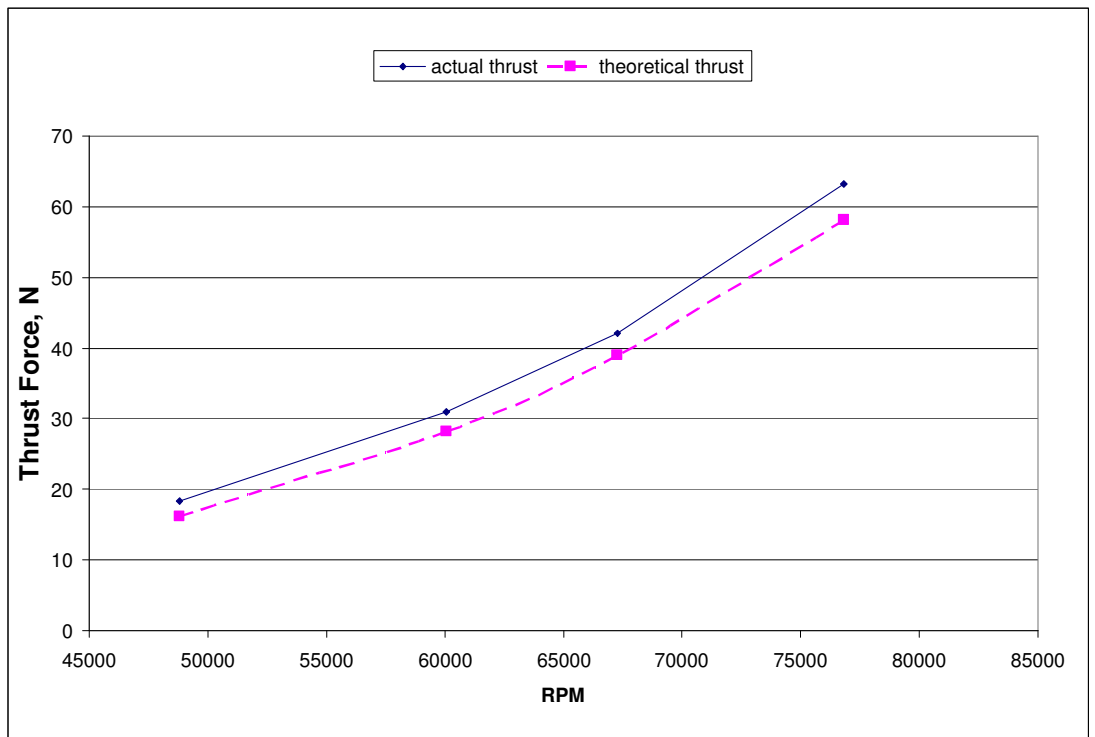

Figure 16: Measured and theoretical jet engine thrust force versus rotational speed 


\section{Lift, Drag and Introduction to Aerodynamics}

\section{$\underline{\text { Educational Objectives }}$}

1. To understand airfoil pressure distributions and how they relate to lift and drag.

2. To understand lift and drag characteristics of airfoils.

3. To understand the effects of camber, angle of attack, and stall on airfoil lift.

4. To understand the effect of approach flow velocity on lift and drag forces and on the coefficients of lift and drag.

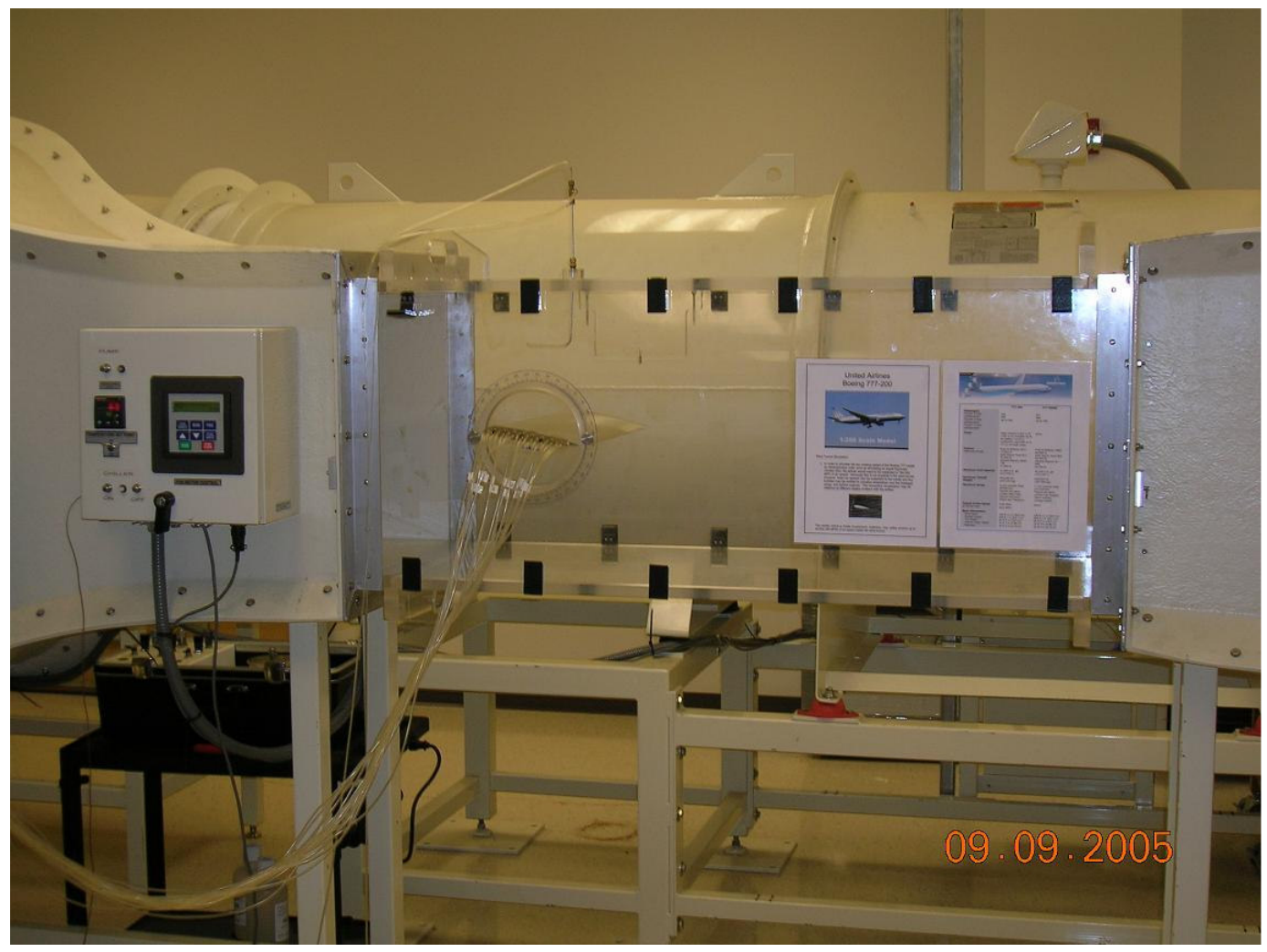

Figure 17: The 30-horsepower re-circulating Wind Tunnel 


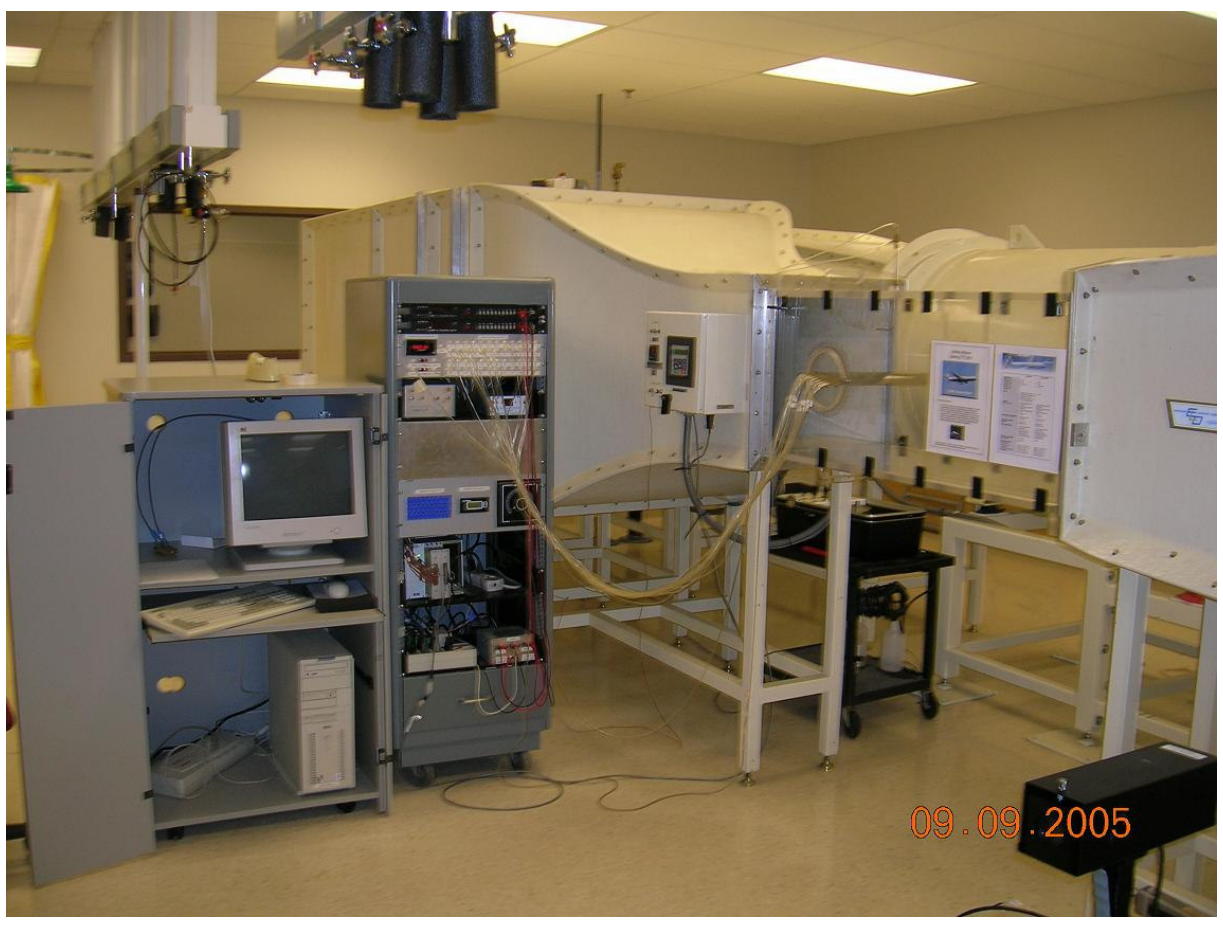

Figure 18: Automatic data acquisition system for the re-circulating Wind Tunnel

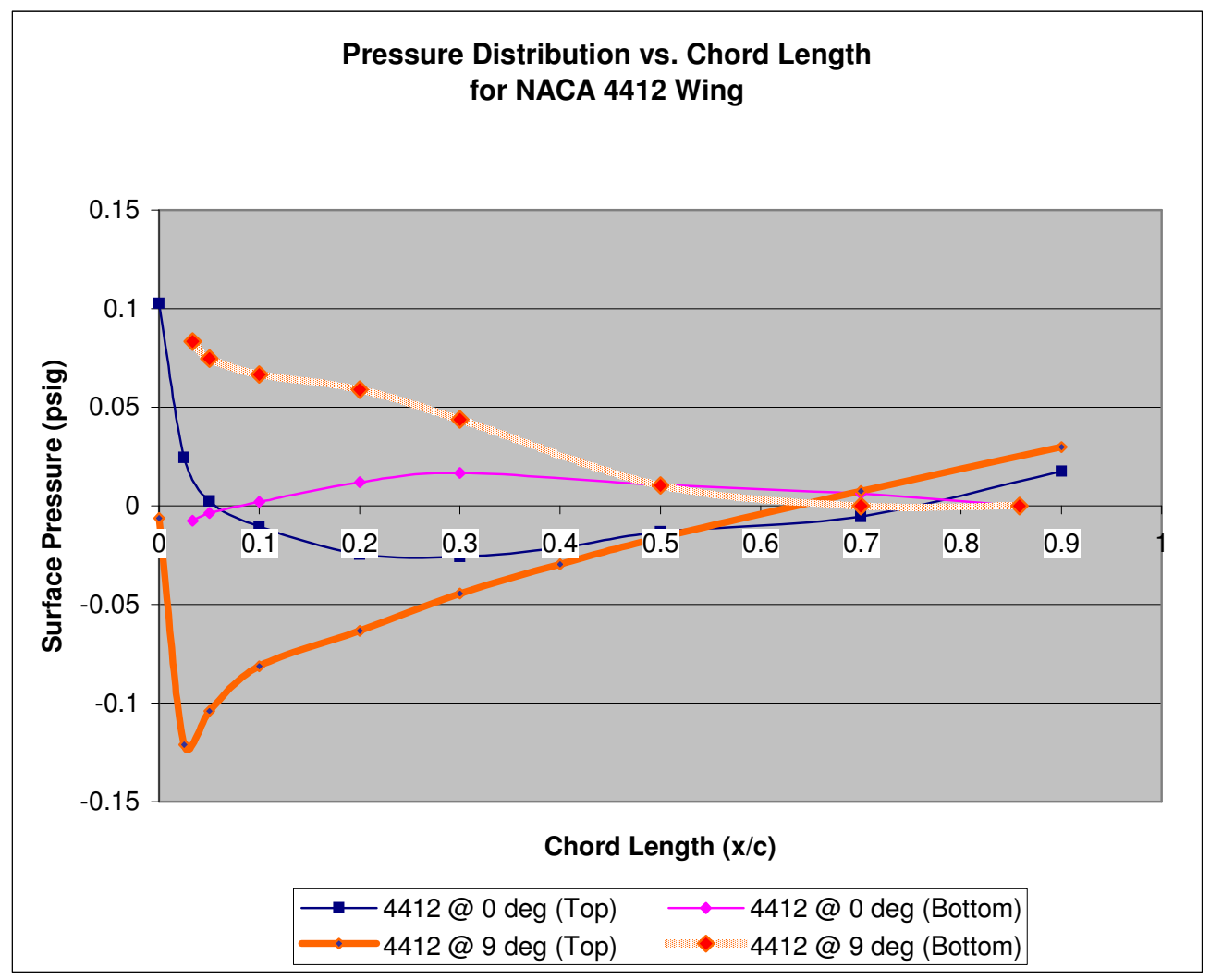

Figure 19: Surface pressure variation on a cambered wing

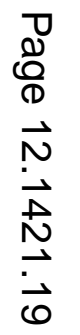




\section{Cylinder Convection}

\section{$\underline{\text { Educational Objectives }}$}

1. To determine the change in surface temperature around the circumference of a heated cylinder in cross-flow.

2. To compare the experimentally measured convection coefficients with published values.

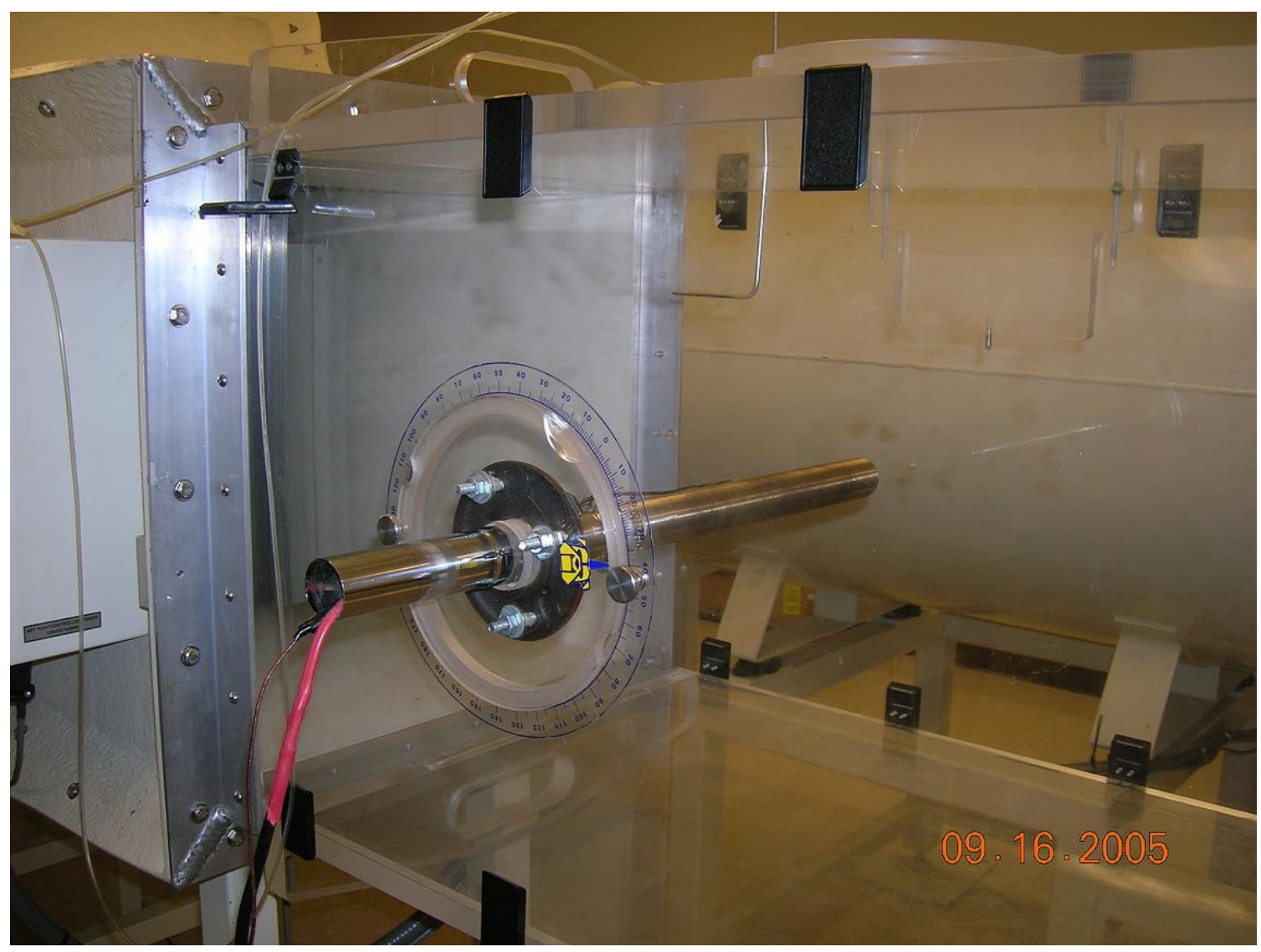

Figure 20: Heated cylinder in cross-flow 
Nusselt number vs. Reynolds number

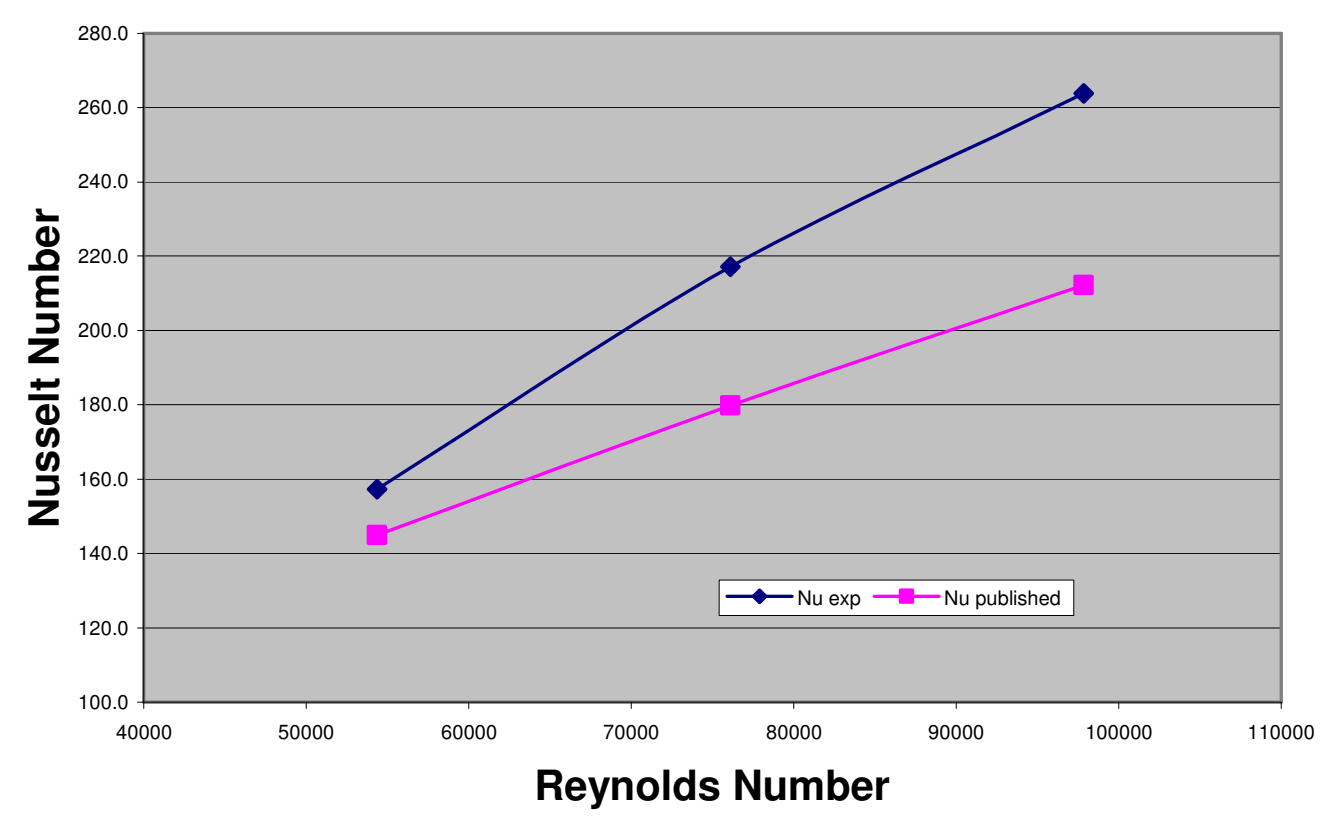

Figure 21: Experimental and actual Nusselt number vs. Reynolds number

\section{Discussion}

In addition to the experiments shown above, a design project is included in this laboratory course. Student teams propose their own project in the general area of Energy Conversion. Although building a device is not required, most teams design, build and demonstrate their project during the last day of class. These projects are funded through proceeds from the sale of the laboratory textbook ${ }^{1}$. Some completed projects become permanent displays in the laboratory.

Future plans include the addition of a Fuel Cell Air Management System and a Thermal Shock Chamber. They will be used for experiments involving flow and humidity control and transient conduction, respectively.

\section{Conclusions}

Energy Systems Laboratory is an integral part of the mechanical engineering core at Kettering University. This modern laboratory educates the students in the area of energy conversion, thermodynamics, fluid flow and heat transfer. It is continuously updated and improved to integrate well with Kettering University's world class mechanical engineering curricula. It provides an opportunity to about 250 mechanical engineering students per year to become familiar with the analysis of numerous energy systems by applying the principles of thermodynamics, fluid mechanics and heat transfer in an integrated manner. 


\section{Bibliography}

1. Pourmovahed, A. and Navaz, H.K., Energy Systems, 2e, John Wiley \& Sons, ISBN 0-471-74421-2, 2005.

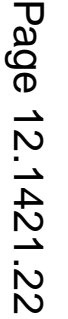

